\section{A CRITICAL REVIEW OF PRESENT DE- VELOPMENTS IN VOCATIONAL GUIDANCE WITH SPECIAL REFERENCE TO FUTURE PROSPECTS}

\author{
George E. Myers \\ Professor of Vocational Education \\ University of Michigan
}

The first development to which I wish to call attention is a growing recognition of vocational guidance as an integral part of organized education, not as something different and apart from education that is being wished upon the schools by a group of enthusiasts because there is no other agency to handle it. Out of the fog of discussion that for years has surrounded the subject of this evening's consideration it has become increasingly clear that helping the youth to obtain reliable and significant information upon which to base a choice of occupation, directing him in his preparation, helping him to find a suitable opportunity to begin work in the occupation of his choice, and giving him additional assistance as needed during the period of adjustment and further training after employment begins, are just as truly educational service as teaching the same youth history or mathematics. It may be added that the former service is likely to have a far more vital bearing upon his satisfaction in life and his contribution to society than the latter. This conception of vocational guidance as an integral part of organized education, and not as something added on, is fundamental. Acceptance or rejection of it affects the budget, the plan of organization and administration, and the methods of carrying on the work. Orderly, systematic progress in vocational guidance commensurate with its importance is dependent in large measure upon the extent to which this fundamental conception prevails.

Second, vocational guidance is becoming recognized as a specialized educational function requiring special natural qualifications and special training. Time was, and that not very long ago, when the principal, in addition to a multitude of other duties, was expected every now and then to pull out of the air, or out of a very meagre experience, vocational advice for his boys and girls who face hundreds of possible occupations. In fact, this is still the situation in most high schools and junior high schools. Nor is it long since the burden of assisting pupils to obtain information upon which to base occupational choices was laid at the door of the already overburdened teacher of English. While valuable work has been done in these ways, experience has shown that few teachers have the personal qualities, and fewer still have the necessary knowledge, for effective counseling, while all are too busy with their regular duties to give the vocational interests and needs of their boys and girls adequate attention. If the job is to be well done it must be the sole business, or at least the principal business, of one who is prepared to do it. The comprehensive programs for training vocational counselors, printed in the current Yearbook of this Society, are evidence of the changing attitude on this matter. The institutions offering this training have marked off fairly definite bodies of knowledge and a fairly definite technique to be mastered by one who prepares for the work of counselor. These programs are not perfect, to be sure, but any one who examines them will admit that substantial progress has been made in comparison with what was offered five or even three years ago. Future progress will gradually bring us to the point where school authorities will be concerned at least as much about the special preparation of the vocational counselor as of the high school teacher of English or Latin or Physics. In many cases, to be sure, the counselor will have had preparation for teaching some special subject plus experience in teaching, both of which should be valuable to him. But he will have had also considerable preparation in the special field of vocational guidance.

A third development that claims attention is an increasing appreciation that a centralized, unified program of vocational guidance for the entire school system of a city is essential to the most effective work. We are rapidly passing out of the stage when each high school and junior high school can be left to organize and conduct 
vocational guidance as it sees fit. In order to realize the importance of this development it is only necessary to recall that a comprehensive program of guidance involves, among other things, gathering information concerning all of the important occupations of the city, preparing this information for use by counselors and pupils, keeping constantly in touch with the immediate demands of industry and business for young workers, and finding out how the young worker fits the job he has undertaken.

This work brings the school system into relations with business and industry more than all other school work combined. A vocational guidance program simply does not function without these contacts. To avoid needless duplication of effort and constant "crossing of wires" it is essential that the contacts be made through a single agency representing the entire school system, rather than through several high schools and junior high schools separately. Furthermore, the centralized organization provides opportunity for careful supervision over the counseling done in the various schools, and makes possible a piece of work fairly uniform in its effectiveness throughout the school system. In view of what has already been said, it seems clear that no other activity of the school system has greater need of a centralized, unified program than has vocational guidance. Development along this line, already well under way, seems sure to be general throughout the United States. In fact there is danger that this development will proceed more rapidly than suitable city directors can be prepared to have charge of the work.

An interesting and promising development is the growing attention given to vocational guidance in our colleges and universities. It is only a few years since Dean Keppel of Columbia University found that college men were surprised that any one should harbor the idea that they could obtain help from their professors in choosing a vocation. Our colleges and professional schools have been very ready to say to students who fail to measure up to academic standards: "You don't belong here." We have not tried to help these men find out where they do belong. Nor, still more important, have we asked those who stay and do the work whether or not they ought to be doing this particular work rather than something else. Many a time we have tried, and been perfectly satisfied in trying, "to make a psychologist out of a man meant by nature to be an engineer," as Professor Cattell puts it. And too often when the course of training was completed we have waved a hasty "good-bye, I wish you luck," and turned to the next year's class, leaving the inexperienced graduate to flounder into any kind of position he may, regardless of whether or not it calls for the priceless native capacity he possesses or the costly training he has obtained. While the situation in many colleges, as far as actual aid to students is concerned, has not yet improved materially over what it was when Dean Keppel made his investigation, there is ample evidence in the current Yearbook of a widespread interest among college faculties in this subject and of a few efforts to organize real vocational guidance service. The efforts have varied from an occasional "vocational conference" in charge of a student committee to the well organized "personnel bureau" with a director and small staff devoting their entire time to this work. The college or university personnel bureau is new. It is still too new for its functions to be clearly defined, to say nothing of having its effectiveness judged. Nevertheless, this type of organization seems logical and gives promise of greater success than any other. It is based upon the assumption that the college and university have as definite responsibility to their students and to society to aid students in choosing vocations wisely and entering these vocations advantageously, as they have for providing general education or preparation for vocations already chosen, perhaps by chance. It recognizes also the specialized character of the service to be rendered and provides a centralized direction, both of which have been found important in public school guidance programs.

Another development that impresses one is the disposition of leaders in vocational guidance to stress research. It has been clear throughout this evening's discussion 
that any guidance worthy of the name must be based upon reliable and significant data concerning vocations. The current Yearbook of this Society is full of evidence that an enormous amount of factual material of this kind must be accumulated and kept up to date. Numerous investigations for this purpose have been carried on. Several studies of the occupational interests of boys and girls while still in school have been conducted. Studies have been made of the jobs at which young workers find employment during the first few years after leaving school. Other studies of varied character have been made. To be sure, many investigations in the vocational guidance field, as in every other field, have been amateurish and of little value. The important thing and the thing stressed here is that a steadily growing emphasis is placed upon research and the research spirit among workers in this field. However, notwithstanding what has already been done and the interest shown, vocational guidance research is still in the kindergarten stage. Investigations are needed to clear up our objectives. Others are needed that deal with organization and administration, especially in the college field. The technique of counseling and of placement calls for extensive study. Standardized tests of vocational aptitudes and performance need to be developed and evaluated. Far more light is needed on the significance of intelligence ratings for vocational guidance. Try-out, or exploratory, courses need to be investigated in order to determine whether they are performing the functions for which they were developed, and whether courses along other lines should be added. Possibilities of coöperation between the public school guidance office and other social agencies of the community should be studied. And a whole group of problems worthy of investigation cluster around the "follow-up" of those who have been placed through a guidance program. The nature of vocational guidance and its relation to the business, industrial, and professional life of the community are such that it must cultivate the spirit and methods of research if it is to be really effective in the long run.

This discussion should not close without calling attention to a couple of tendencies that threaten the effectiveness of the vocational guidance program. One of these is the tendency of the school placement office to become a mere job-finding office, judged as to its efficiency by the number of boys and girls placed in any kind of jobs, rather than by its success in placing them in positions for which they are suited. No school vocational guidance program can claim to be comprehensive without a placement service. In fact, the public school placement office should gradually come to be the principal source of supply for junior workers in the community it serves. The extent to which employers look to this office for young workers may well be considered a measure of its success. But employers will not become regular patrons of a placement office unless it gives them discriminating service. Nor is any other kind of service of real permanent value to the boy or girl seeking employment. A mere job-finding office is not a legitimate part of a vocational guidance program.

Another tendency dangerous to the cause of vocational guidance is the tendency to load the vocational counselor with so many duties foreign to the office that little real counseling can be done. The principal, and often the counselor himself, has a very indefinite idea of the proper duties of this new officer. The counselor's time is more free from definite assignments with groups or classes of pupils than is that of the ordinary teacher. If well chosen he has administrative ability. It is perfectly natural, therefore, for the principal to assign one administrative duty after another to the counselor until he becomes practically assistant principal, with little time for the real work of a counselor. In order to prevent this tendency from crippling seriously the vocational guidance program it is important that the counselor shall be well trained, that the principal shall understand more clearly what counseling involves, and that there shall be efficient supervision from a central office.

Five developments in vocational guidance that are significant for future progress have been presented in this brief paper: first, a growing recognition of vocational 
guidance as an integral part of organized education and not as something added on; second, an increasing appreciation that vocational guidance is a specialized educational function requiring special natural qualifications and special training; third, a growing belief in a centralized type of organization and supervision that has direction of the guidance program for the entire educational system of the community; fourth, an awakened interest in, and the beginnings of intelligent planning for, vocational guidance in the colleges and universities; and fifth, a growing realization of the necessity for extensive research in the guidance field.

In addition, attention has been called to two tendencies that, unless checked, will interfere seriously with future progress, namely, a tendency for placement work to degenerate into mere job-finding, and a tendency to load the vocational counselor with other work so that it becomes impossible for him to perform the real duties of a counselor.

\section{WHAT IS THE GUIDANCE EMPHASIS IN OUR PUBLIC SCHOOLS?}

\section{A. H. Edgerton}

\section{Teachers College and the Lincoln School Columbia University}

Note. The following excerpts have been selected from the somewhat detailed reports which are contained in Chapter I of Section I, Part II, of the Twenty-Third Yearbook of the National Society for the Study of Education. These data have been secured from investigations of 143 large and small public school systems.

Of the various guidance and counseling activities which have been provided in the 143 large and small city systems investigated the most important provisions may be grouped as follows:

I. Collecting occupational information and making it available to pupils:

1. Through central office surveys, source bulletins, opportunity literature, etc.
2. Through contact with employment problems of junior workers, etc.

3. Through excursions, reports, posters, and charts for showing industrial opportunities, moving pictures, etc.

II. Interviewing and conferring with pupils, parents, and others concerned in order:

1. To assist in the selection of courses of study and training programs.

2. To assist pupils in the study and choice of vocations.

3. To assist, through the services of the placement bureau, those planning to drop out of school.

4. To consider failures referred by scholarship committees or others, to determine cause and possible remedy for same.

5. To assist pupils desiring change of school subjects or programs.

6. To provide groups with $(a)$ talks on occupations in general, and (b) talks for those interested in specific vocations.

7. To counsel students desiring working permits for steady employment, for after school work, etc.

8. To follow up and help adjust graduates and former students, etc.

III. Contributing to curriculum building and the adjustment of pupils to meet occupational needs and interests.

IV. Recording results of school performance and measurements:

1. By adapting records (psychological tests, self analysis, cumulative data) to educational and occupational needs.

2. By keeping records of case studies, etc.

V. Acquainting the public with educational problems:

1. Through contact with prospective students.

2. Through parent-teacher organizations.

3. Through newspapers, industrial organizations, commercial clubs, etc. 